\title{
Non Alkolik Yağlı Karaciğer Hastalığında Güncel Medikal Tedavi
}

\author{
Current Medical Treatment in NAFLD
}

\author{
Akif ACAY \\ Sağlık Bakanlığı Mecitözü Devlet Hastanesi, İç Hastalıkları Kliniği, Çorum
}

\section{ÖZET}

Non Alkolik Yağlı Karaciğer Hastalığı, en yaygın karaciğer hastalıklarından biridir. NAYKH, obezitenin dünya epidemisiyle paralel olarak artmaktadır. NAYKH, basit yağlanmadan steatohepatite, ileri fibroz ve siroza ilerleyebilir. Kanıtlar; insülin direnci, oksidatif stres ve genetik faktörlerlerin interaksiyonunu içeren çoklu mekanizmaların NAYKH'nın gelişimini başlattığını göstermektedir. Halen onaylanmış bir ilaç tedavisi olmamasına rağmen pek çok yaklaşımın faydalı olabileceği göz önünde bulundurulmalıdır. İnsülin duyarlaştırıcılar, antioksidanlar, antilipidemik ilaçlar ve antiinflamatuar ilaçların faydalı etkileri gösterilmiştir. Bu yazıda NAYKH' nın mevcut tedavisi ve potansiyel yeni tedaviler üzerine odaklanılmıştır.

Anahtar Kelimeler: naykh, güncel, tedavi

\section{ABSTRACT}

Nonalcoholic fatty liver disease is one of the most prevalent liver disease. NAFLD is increasing in parallel with the worldwide epidemic of obesity. NAFLD may progress from simple steatosis to steatohepatitis, advanced fibrosis and cirrhosis. Several evidences suggest that multiple mechanisms including insulin resistance, oxidative stress, inflammation, and genetic factors interact to initiate the development of NAFLD. Despite that there is currently no approved drug therapy for NAFLD, many approaches consider to be beneficial. Insulin sensitizers, antioxidants, antilipidemic drugs and antiinflammatory agents showed promising effects. This paper is focused on the currently treatments for NAFLD.

Keywords: nafld, current, treatment

olan "Nonalcoholic fatty liver disease" (NAFLD) "Alkole bağıı olmayan yağlı karaciğer hastalığı" kavramı ön plana çıkarılarak NASH bu kavramın altında değerlendirilmeye başlanmıştır.

Karaciğer yağlanması: Herhangi bir nedene bağlı olarak ortaya çıkan karaciğer yağlanmasını ifade eder.

Non-alkolik Yağlı Karaciğer Hastalığı: Alkol dışı bir çok nedene bağıı karaciğer yağlanmasını anlatır.

Non-alkolik Steatohepatit: Karaciğerde yağlanmaya ilave olarak nekroenflamasyon bulunmasını ifade eder.

Karaciğer yağlanma tipleri: Bir çok kaynakta karaciğer yağlanması, mikroveziküler yağlanma, makroveziküler yağlanma ve mikst tipte yağlanma olmak üzere 3 tipe ayrılır. Ayrıca, nedenleri bakımından da yağlanma akut ve kronik yağlı karaciğer hastalığı olarak ikiye ayrılır. 
Akut yağlanma nedenleri: Gebeliğin Akut Yağlı Karaciğeri, Reye Sendromu, ilaçlar (kortikosteroidler, tetrasiklin, amiodaron, sodyum valproat) ve toksinler (karbon tetraklorür, fosfor bileşikleri) gösterilmektedir.

Kronik yağlanma nedenleri: Alkol, obezite, diabetes mellitus, hiperlipidemi, jejunoileal by-pass, protein kalori malnütrisyonu, total parenteral beslenme, kronik hepatit $\mathrm{C}$, Wilson hastalığı, inflamatuvar barsak hastalıkları ve AIDS gösterilmektedir $(1,2)$.

\section{PATOGENEZ}

NAYKH'nın patogenezi halen net olarak bilinmemekle beraber, hem çevresel hem de genetik faktörlerin bir kombinasyonu şeklinde multifaktöriyel olarak ortaya çıktğı düşünülmektedir. Yağ dokusunda de novo yağ sentezi artışı, yağ dokusundan artmış nonesterifiye yağ asitleri salınımı ve diyetle aşırı yağ alımına karşın bozuk hepatik trigliserid atılımı ile azalmış beta oksidasyon sonucu ortaya çıkan dengesizliğin hepatositlerde yağlanmaya neden olduğu düşünülmektedir (3). Patolojik süreçle ilgili bir çok teori vardır ancak, en kabul göreni "two-hit hypothesis" denen çift vuruş hipotezidir. Yağlanma ile neticelenen hastalık sürecinde ilk darbe insülin direncidir. İnflamasyon ve fibrozisi getiren ikinci darbeden de, oksidatif stres, mitokondrial fonksiyon bozuklukları, tümör nekrozis faktör- $\alpha$ (TNF $\alpha$ ) gibi sitokinler ve adiponektin, leptin gibi hormonlar sorumludur (1). NAYKH'da 4 tip patolojik değişiklik olur (Tablo 1). Yağ depolanmasına ilave olarak başlayan inflamasyonu, giderek şiddetlenen ileri inflamasyon ve balonlaşma dejenerasyonu takip eder. Bu süreç devam ederse; fibroz, mallory cisimciği ve sirozu takiben karaciğer yetmezliği gelişir $(4,5)$.

\section{Tablo 1 (NAYKH'da görülen patolojik değişiklikler)}

1- Sadece yağ depolanması

2- Yağ depolanmasına ilave inflamasyon

3- Yağ depolanması ve ileri inflamasyona ilave balonlaşma dejenerasyonu.

4- Illk 3 tip değişikliğe ilave fibrozis ve/veya mallory cisimciği ve sirotik değişiklikler.

\section{NAYKH' , ile ilişkili durumlar}

Obezite: NASH'li hastaların büyük kısmı obezdir. Ayrıca, obezite şiddeti ile hastalık şiddeti koreledir.

Diabetes Mellitus: NASH'li hastaların \%75' inde diabetes mellitus vardır. Obez, orta yaşlı DM'li hastalarda ultrasonografi ile NAYKH'ı saptama olasılığı oldukça yüksektir.

Hiperlipidemi: NASH'li hastalarda \%20-80 oranında yüksek kan kolesterol ve trigliserid düzeyi vardır.

\section{Diğerleri:}

- Uzun süreli total parenteral nutrisyon

- Ciddi insülin direnci

- Obezlerde hızlı kilo kaybı

- Ailevi lipid hastalıkları

- Kortikosteroid, Metotreksat, Tamoksifen kullanımı (4).

\section{TANI}

\section{Semptom ve Bulgular}

NAYKH'da genelde semptom olmaz veya sağ üst kadran ağrısı, halsizlik gibi nonspesifik semptomlar olabilir. Muayenede ise hepatomegali, sağ üst kadranda palpasyonla ağrı gibi nonspesifik muayene bulguları tespit edilebilir. NAYKH, fibroz veya siroza ilerlediğinde semptom ve bulgular zenginleşir. Klinik incelenirken dikkat edilmesi gereken hususlardan birisi de alkol kullanan yağlı karaciğer hastalarından hangisine alkolik karaciğer hastalığı, hangisine non-alkolik yağlı karaciğer hastalığı deneceği konusudur. Burada 140 gr/hafta alkol tüketimi sınır kabul edilmiştir (1).

\section{Laboratuvar}

Hastalar genelde artmış karaciğer fonksiyon testleri ile insidental olarak saptanır. Hepatik transaminazlar üçte iki hastada normal olmakla birlikte hastaların üçte birinde tipik olarak alanin aminotransferaz (ALT) daha fazla olmak üzere transaminaz seviyeleri artmıştr. Ancak, tanı için hepatik transferazlarda artş̧ yapan viral hepatitler, otoimmun hepatit, alkolik hepatit, Wilson hastalığı, hemakromatozis, alfa-1 antitripsin eksikliği, kortikosteroidler, antiretroviral tedavi, tamoksifen kullanımı gibi toksik hepatit yapan durumlar ekarte edilmelidir (1). 


\section{Radyoloji}

NAYKH şüphesi olan hastada ilk tercih ultrasonografi (USG) olmalıdır. Ucuz, kolay ulaşılabilir ve non-invaziv olması tercih sebebidir. Yağlı karaciğer USG'de dalak ve böbrek ile kıyaslandığında hiperekojen görülür. Fakat USG yağ miktarını kantitatif ölçemediği gibi histolojik hastalık hakkında da fikir veremez. Diğer dezavantajları, kullanıcı bağımlı olması ve şişman hastalarda daha az hassas olmasıdır. Bilgisayarlı Tomografide ise yağlı karaciğer, dalağa kıyasla daha hipodens görülür. Bu tanı yöntemi de yağ miktarının kantitatif tayininde zayıftır. Manyetik Rezonans Spektroskopi (MRS) halen karaciğer yağlanmasında teşhisde daha sensitif ve yağ miktarını belirlemede daha faydalıdır. Szczepaniak ve arkadaşları, 2005 yılında karaciğerdeki yağ miktarını ölçmede biopsi ile MRS'yi karşılaştırdıkları çalışmanın sonucuna göre, biopsi ve MRS'nin yağ tayinlerinin iyi düzeyde korele olduğu saptanmıştir. Bu yöntemin dezavantajları ise pahalı olması ve çok az merkezde yapılabiliyor olmasıdır (6).

\section{Biopsi}

Karaciğer biopsisi; çoğunlukla NASH tanısı, steatohepatit derecesi ve fibrozis aşamasını tespitte kullanılır. Karaciğer biopsisi, USG eşliğinde daha güvenli olsa da bu yöntem medikal tedaviye zayıf katkısı ve invaziv olması nedeniyle hekimler tarafindan nadir olarak tercih edilir. Şu anda, karaciğer biopsisi diğer tanıları dışlamada ve klinik risk faktörlerinin varlığında NASH tanısını doğrulayıp tedavi kararını vermede en iyi yöntem olarak görülmektedir (6).

\section{Diğer güncel non invaziv yaklaşımlar}

Hepatosteatoz ve NASH'i tanımada bazı güncel çabalar mevcuttur. Transient elastografi, karaciğerde fibrozisi ve evresini tespit etmede kullanılan, güncel, USG destekli bir metoddur. Elastografi fibrozu saptamanın yanında portal hipertansiyon teşhisinde de fayda sağlar (7). Yine NASH'de 'caspase-cleaved cytokeratin-18 (CK18)' olarak isimlendirilen bir biomarker umut vadetmektedir. NASH'de apopitoza bağlı hepatosit ölümü ve önemli ölçüde kaspaz aktivasyonu vardır. NASH'de cytokeratin-18 (CK-18) protein düzeyinin, hepatosteatozlu kontrol grubu ile kıyaslandığında önemli ölçüde arttığı bir çok çalışma ile gösterilmiştir (6).

\section{TEDAVi}

NAYKH, kronik karaciğer hastalığının önemli bir sebebidir. Tedaviye başlama kararı, NAYKH'nın NASH'e dönüştükten sonra siroz ve kansere ilerleme riski göz önünde bulundurularak verilmelidir (8). Tedaviye, tüm hastalarda ilaçtan önce diyet ve egzersiz ile başlanmaIıdır. Illaç tedavisi; patogenezde rol oynayan obezite, diabetes mellitus ve hiperlipidemi gibi hastalıkların durumuna göre şekillendirilmelidir $(9,10)$. Karaciğer yağlanmalarının tedavisinde günümüze kadar bir çok ilaç araştırımıştır. Ancak, tedaviye yönelik spesifik bir ilaç henüz ruhsatlandırma aşamasına gelememiştir. İnsülin direnci NAYKH'nda önemli bir problem olarak karşımıza çıkmaktadır. Bu açıdan kullanılan ilaçlar insülin direncini hedeflemelidir. NAYKH'da insülin direncini azaltan ilaçlar biguanidler (metformin), glitazonlar (roziglitazon, pioglitazon) ile hepatoprotektif veya antifibrojenik olduğuna inanılan ursodeoksikolik asit (UDCA), betain, vitamin E, lesitin, beta-karoten and selenyum gibi ilaçlar çalışma aşamasındadır (8). NAYKH'nda kullanılan ilaçlar Tablo 2'de derlenmiştir.

Tablo 2:

\begin{tabular}{|c|c|c|c|}
\hline $\begin{array}{l}\text { İnsülin duyarlılığını } \\
\text { artıranlar }\end{array}$ & $\begin{array}{l}>\text { metformin } \\
>\quad \text { pioglitazon }\end{array}$ & Antilipidemikler & $\begin{array}{l}>\text { Atorvastatin } \\
>\text { Fenofibrat } \\
>\text { Klofibrat } \\
>\text { Gemfibrozil }\end{array}$ \\
\hline $\begin{array}{l}\text { Hepatoprotektif ajanlar } \\
\text { (Antifibrojenik) }\end{array}$ & $\begin{array}{ll}> & \text { Ursodeoksikolik asit } \\
> & \text { Taurin } \\
> & \text { Lesitin } \\
> & \text { Beta karoten }\end{array}$ & Anti-obezite ilaçları & $\begin{array}{l}>\text { Orlistat } \\
>\quad \text { Sibutramin }\end{array}$ \\
\hline Antioksidanlar & $\begin{array}{l}>\mathrm{N} \text {-asetil sistein } \\
>\text { Betain } \\
>\text { Vitamin }-\mathrm{E}\end{array}$ & Diğerleri & $\begin{array}{l}>\text { Metranidazol } \\
>\quad \text { Probiyotikler } \\
>\quad \text { Omega } 3 \text { yağ asitleri }\end{array}$ \\
\hline
\end{tabular}




\section{Yaşam tarzı değişikliği (kilo kaybı ve fiziksel aktivite)}

NAYKH 'da kilo azalması hem serbest yağ asidi dağıllmını düzenler hem de periferik glukoz kullamını art-rarak ekstrahepatik insülin duyarlılığını artırır. Ayrıca, adipoz dokudaki inflamasyonu ve serbest oksijen radikallerini azaltr. Kilo verme aşamalı olmalı ve bazal vücut ağırlığının yaklaşık \%5-10 kadar olmalıdır. Son çalışmalar kilo verme ile transaminaz düzeylerinde ve lipid parametrelerinde önemli düzelme olduğunu göstermiş̧tir. Fiziksel aktivite, glukoz dengesi ve artmış insülin duyarlılığı gibi kilo kaybından bağımsız faydaIı etkilerinden dolayı NAYKH'nın tedavisine entegre olmuştur. Ayrıca; fiziksel aktivite, hepatik trigliserid toplanmasını azaltır ve vücutta lipid oksidasyonunu düzeltir (11). Sonuç olarak, hepatosteatozdan kronik karaciğer hastalı̆ı̆na kadar NAYKH'nın her döneminde medikal tedaviden önce mutlaka yaşam tarzı değişikliği ön plana çıkarılmalıdır.

\section{Medikal Tedavi}

\section{Ursodeoksikolik asit}

Ursodeoksikolik asit (UDKA) barsakta kenodeoksikolik asitin $7 \beta$ epimerizasyonu sonucu oluşur ve safra asit havuzunun \%1-3'ünü oluşturur (12). UDCA nükleer farnezoid X-reseptör vasıtasıyla insülin duyarlıIı̆̆ını artırır. UDKA, GLP-1 sekresyonunu stimüle edip NAYKH'nda antioksidatif defans sistemini güçlendirir. UDCA, NASH'li hastalarda adiponektin seviyelerini restore edip hepatosit apopitozunu azaltmanın yanı sıra, karaciğer fonksiyon testlerini ve histolojik görüntüyü düzeltir. Ancak bazı çalışmalar bu verileri doğrulamamaktadır (13). NASH'li hastaların çoğu 30 yaş üzeri erkek hastalar olup \%80'i obezite ve tip 2 diyabet ile ilişkili bulunmuştur. Ayrıca, hastaların \%15-50'sinde fibrozis, \%5-9'unda siroz gelişir $(14,15)$. UDKA bir çok çalışma ile NAYKH'nda denenmiştir. Lindor ve arkadaşlarının yaptığı 168 hastanın katıldığı çalışmada, UDKA tedavisi alan grup ve plasebo grubu arasında histolojik değişiklikler bakımından anlamlı farklııı saptanmamış$\operatorname{tr}$ (16). Yine Vajro ve arkadaşlarının yaptığı çalışmada, pediatrik yaş grubu hastalarda UDKA tedavisinin karaciğer fonksiyon testleri üzerine düzelme sağlarken, histolojik düzelme üzerine etkili olmadığı gözlemlenmiştir (17). Adams ve arkadaşlarının yaptığı bir başka çalışmada yüksek doz UDKA tedavisi kullanılan hastalarda 6 aylık tedavi sonrası hepatik transaminazlar, alkalen fosfataz(ALP) ve gama-glutamil transferaz (GGT) düzeylerinde anlamlı düzelme olmazken, bilirubin düzeylerinin gerilediği gözlemlenmiştir (18). Pietu ve arkadaşları sürekli karaciğer enzim yüksekliği olan histolojik olarak NASH'li olduğu tespit edilen bir grup hastada, UDKA ve Vitamin-E kombinasyonu ile ALT, AST ve GGT düzeylerinde anlamlı düşüş saptamışlardır (19). Nihai olarak, UDKA tedavisinin çoğu çalışma ile etkili olduğu gösterilmiş olsa da, UDKA tedavisine statin, glitazon ve vitamin E ilave etmenin daha etkili olduğu söylenebilir (13).

\section{Pioglitazon}

NAYKH'nda insülin direnci bilinen önemli bir sorundur. Bu noktadan hareketle, insülin duyarlaştırıcı ilaçlar değişik çalışmalarla tedavide denenmiştir. Pioglitazon, insülinin hedef hücrelerindeki PPAR-gama (peroksizom proliferatörünü aktive eden reseptör- gama) reseptörlerini aktive ederek insülin duyarlıığını artırırlar ve insülin salgısını artırmadıkları için de hipoglisemi yapmazlar. Diğer bir etkisi de; Glukoz Transfer Protein tip-4'lerin (GLUT-4) sentezini arttrarak, çizgili kas ve yağ hücrelerinde glukoz girişini artırmaktır.

Pioglitazon; insülin duyarlılığını artırdığından NAYKH'nda ilgi odağı olmuştur. Hajiaghamohammadi ve arkadaşları; pioglitazon, metformin ve silmarin'i karşılaştırdıkları bir çalışmada NAYKH olan hastalardan oluşmuş 3 ayrı gruba, her gruba ayrı ilaç olmak şartiyla bu 3 ilacı vermişlerdir. 8 hafta sonra hastalar değerlendirildiğinde pioglitazon alan grupta serum lipidleri, AST, ALT ve insülin direncinde önemli azalma saptamışlardır. Metformin ve silmarin alan diğer gruplarda ise ALT ve AST değerleri, pioglitazon grubuna kıyasla daha az olmakla birlikte kısmi düzelme saptanmıştr(5). Shyangdan ve arkadaşlarının insülin duyarlaştırıcılarını inceledikleri bir derlemede, pioglitazon, roziglitazon ve metformin kıyaslanmış; sonuç olarak ALT ve AST gibi parametrelerde düzelme tespit edilmiştir. Fakat, yeni çalışmaların karaciğer biopsileri ile desteklenip histolojik düzelmenin aranması gerektiğinin alt çizilmiştir (20). Boettcher ve arkadaşları NASH'li hastalarda yaptıkları plasebo kontrollü bir çalışmada, pioglitazon ve roziglitazon ile karaciğerde histolojik düzelmeyi araştırmışlardır. Sonuç olarak plaseboya kıyasla pioglitazon grubunda karaciğer nekroinflamasyonunun, yağlan- 
manın, lobuler inflamasyonun ve balonlaşma dejenerasyonunun önemli ölçüde düzeldiği görülmüştür (21). Gastaldelli ve arkadaşları, NASH'li hastalarda pioglitazon tedavisinin adiponektin düzeylerini artırdığını ve bu durumun karaciğer histolojik düzelmesi ile korele olduğunu yaptıkları bir çalışma ile göstermişlerdir (22).

\section{Metformin}

Biguanid grubu bir insulin duyarlaştırıcı ilaçtır. Metforminin glukoz düşürücü etkisi başlıca azalmış hepatik glikoz çıkışı (primer olarak glukoneogenezin ve daha az olarak da glikojenolizisin inhibisyonu yoluyla) ve iskelet kasında ve adipositlerde artmış insülin aracılı glikoz alımı ile ortaya çıkmaktadır. Bu etkilerine ek olarak, intestinal glukoz emilimini de azaltmaktadır. Metforminin kardiyovasküler olayları azalttğı gösterilmiştir. Ayrıca, metforminin tip 2 diyabetli hastalarda antihiperglisemik etkileri yanında kilo kaybı, hiperinsülineminin azalması, lipid profilinin düzelmesi, artmış fibrinolizis ve güçlenmiş endotelyal fonksiyonlar gibi başka yararlı etkileri de vardır (23). Birkaç klinik çalışma ile NAYKH'nda metforminin faydalı rolü desteklenmektedir. Bu çalışmalarda metforminin çeşitli dozlarda, karaciğer enzimleri ve histoloji üzerine olan etkileri incelenmiştir. Marchesini ve arkadaşlarının yaptıkları bir çalışmada, 4 ay boyunca diabeti olmayan NASH'li hastaları iki gruba ayırmışlardır. Gruplardan birincisi diet egzersiz grubu, ikincisi ise günlük 1,5 gr metformin alan iki gruptan teşkil edilmiştir. Çalışma sonunda metformin grubunda, insulin direncinde, aminotransferaz seviyelerinde ve karaciğer morfolojisinde diet grubuna kıyasla önemli gelişme tespit edilmiştir. Bir başka 17 hastanın olduğu küçük çalışmada günlük 1700 mg metformin ile diet kıyaslanmıştır. Hastaların karaciğer biopsilerinde herhangi bir farklılık tespit edilmemiş fakat, metformin alan grupta ALT, AST, ve insulin direncinde önemli düzelme kaydedilmiştir (24). Akçam ve arkadaşlarının obez ve yağı karaciğer hastalığı olan 67 adolesan çocukta yaptıkları çalışmada; hastalar 3 gruba ayrılmış ve birinci grup metformin günlük $850 \mathrm{mg}$, ikinci grup Vitamin E günlük 400 IU ve üçüncü grup diet egzersiz grubu olarak oluşturulmuştur ve hastalar 6 ay izlenmiştir. Çalışmanın sonunda metformin grubunda, diğer gruplara kıyasla insulin duyarlılığında belirgin düzelme olmuştur. Ancak TNF-alfa ve adiponektin düzeyinde önemli fark olmamıştır (25).

\section{Statinler}

NAYKH'nda hipertansiyon (HT), DM ve obezite gibi metabolik sendromun diğer bileşenlerinin dışında dislipidemi sıklıkla görülür. NAYKH'nda dislipideminin nedeni tam anlaşılamamasına rağmen olasılıkla lipoproteinlerin dolaşımdan temizlenememesi ve hepatik düşük dansiteli lipoprotein (LDL) üretimi rol oynamaktadır. Bu lipid düşürücü tedavinin NAYKH'nda kardiovasküler sistem ilişkili mortalitede azalma sağlaması mümkündür. Bunun yanı sıra statin ilişkili ciddi hepatotoksisite riskinde artş̧ söz konusu değildir (26).

Statinler, kolesterol sentezinde hız kısıtlayıcı enzim olan 3-hidroksi-3-metilglutaril kooenzim A'yı (HMG$\mathrm{CoA}$ ) inhibe ederler. Statinlerin HMG-COA inhibisyonu dışında pleotropik etkileri vardır. Özellikle antiinflamatuvar ve antifibrinojenik etkileri nedeniyle $\mathrm{NAYKH}^{\prime} \mathrm{da}$ ilgi odağı haline gelmişlerdir (27). Statinler transaminaz seviyelerini yükselttiklerinden dolayı klinisyenler tarafindan NAYKH'da endişe ile karşılanmışlardır. Nseir ve arkadaşlarının; 1980 ve 2012 yılları arasında yayınlanmış online veriler, insan çalışmalarını içeren prospektif yayınlar ve derlemeleri inceledikleri çalışmalarında, NAYKH'nda lipid düşürücü ilaçların güvenlik ve etkinliklerini değerlendirmişlerdir. Çalıma sonucuna göre lipid düşürücü ilaçların hem güvenli hem de etkili olduklarının tespitinin ynında bazı ajanların yağlanma derecesini belirgin düzeyde iyileştirdiği saptanmıştır (28). Tzefos ve arkadaşlarının kronik karaciğer hastalarında statinlerin etki ve güvenilirliklerini inceledikleri bir başka çalışmada; sonuç olarak dislipidemi ile mücadelede statinler, NAYKH ve kronik Hepatit C'li hastalarda güvenli ve etkili bir seçenektirler (29). Hyogo ve arkadaşları biopsi ile ispatladıkları 42 NASH'li hastanın 12 ay boyunca $10 \mathrm{mg}$ günlük atorvastatin tedavisi ile transaminaz, GGT, LDL, TG, Tip 4 kollajen ve tümör nekroz faktör alfa düzeylerinde azalma ile adiponektin ve HDL düzeylerinde artş saptamışlardır. Ayrıca, laboratuar düzelmesiyle orantılı olarak hastalık aktivitesinde düzelme tespit etmişlerdir (30). Hyogo ve arkadaşları hiperlipidemi ilişkili NASH'de, atorvastatini değerlendirdikleri çalışmalarında, biyopsi ile NASH'li olduklarını tespit ettikleri hiperlipidemisi olan 31 hastaya 24 ay boyunca günlük $10 \mathrm{mg}$ atorvastatin vermişlerdir. Tedavi öncesi ve sonrası hastaların vücut kitle indeksi, lipid profilleri, karaciğer fonksiyon testleri, fibrozis belirteçleri (adiponektin, leptin, tümör nekroz fak- 
tör-alfa) ve bilgisayarlı tomografi ile karaciğer dansitesi ölçülmüştür. Sonuç olarak, tedavi sonrası hastaların \%74.2'sinde transaminazlarda düzelme tespit edilmiştir. Adiponektin seviyeleri önemli ölçüde artmıştır ve tümör nekroz faktör-alfa seviyeleri azalmıştir. Leptin seviyelerinde anlamlı değişiklik olmamıştr. Karaciğer yağlanması ve hastalık aktivitesi önemli ölçüde düzelmiştir ancak 4 hastanın fibrozis evresi ilerlemiştir (31).

\section{Fibratlar (fenofibrat, klofibrat ve gemfibrozil)}

Fibratlar etkilerini 'peroxisome proliferator activated reseptor' (PPAR) olarak isimlendirilen nükleer hormon reseptörleri aracılığıyla lipoprotein metabolizmasını kontrol eden genlerin yazılımında değişiklikler yaparak gösterirler. PPAR'lar çevreden aldıkları sinyalleri genoma taşıyan kopyalama faktörleridir (32). Fernandez-Miranda ve arkadaşları fenofibratın NAYKH'nda klinik ve histolojik düzelmeye etkisini inceledikleri çalışmalarında, biyopsi ile doğruladıkları 16 NAYKH bulunan olguyu 48 hafta boyunca günlük $200 \mathrm{mg}$ fenofibrat ile tedavi etmişlerdir. 3 ayda bir biyokimyasal takip ve 48 hafta sonra tekrar biopsi yapılmıştır. Çalışmanın sonunda hastalarda herhangi bir yan etki oluşmamştır. Lipid profili düzelmiş ve GGT önemli ölçüde azalmıştır. İnsülin seviyeleri ve insülin direnci azalma trendine girmiştir. Vücut kitle indeksinde değişiklik olmamış fakat bir kısım hastada metabolik sendrom düzelmiştir. ALT ve AST düzeylerinde bir kısım hastada düzelme sağlanmıştr. Kontrol biyopsisinde hepatosellüler balonlaşma dejenerasyonunun düzeyinde azalma olmakla beraber yağlanma, lobüler inflamasyon, fibrozis veya hastalık aktivitesinde bir azalma olmamıştır (33). NAYKH'nda fenofibrat ve gemfibrozil gibi lipid düşürücü ilaçlarla yapılan tedaviler bu hastalarda artmış olan kardiyovasküler riski azalttı̆ı göz önünde bulundurulmalıdır. Ayrıca, fenofibrat ve gemfibrozile statin kombinasyonunun biyokimyasal parametrelerde daha iyi düzelme yaptığı ve myopati riskinde artş olmadığı tespit edilmiştir (34). Sonuç olarak, NAYKH'nda fibrat tedavisi karaciğer testlerinde ve metabolik sendromda düzelme yapabilir ancak histolojik düzelme minimaldir.

\section{Liraglutide}

Liraglutid, endojen inkretin olan Glukagon Like Peptid-1'i (GLP-19) taklit eder ve diğer grup oral antidiabetiklerin aksine hipoglisemi yapmaz. Bir miktar kilo verdirici özelliği olan bu grup ilaçlar insülin direncini de azaltrlar. Liraglutid sadece glukozu düşürmez aynı zamanda NAYKH'nda hepatik inflamasyonuda azaltrr. Ohki ve arkadaşları NAYKH olan 82 diabetes mellitus hastasını 3 gruba ayırdıkları çalışmalarında, pioglitazon, sitagliptin ve liraglutid'i karşılaştırmışlardır. Hastaların kilolarını ve biyokimyasal değerlerini takip ettikleri çalışmanın sonunda her üç gruptada ALT, açlık kan glukozu ve hemoglobin A1c (Hb A1c) değerlerinde belirgin düzelme saptanmışlardır. Pioglitazon ve liraglutide grubunda, AST değerleri ve platelet oranı önemli ölçüde azalmıştır. Liraglutide grubunda kilo önemli ölçüde azalmakla beraber sitagliptin grubunda değişmemiş ve pioglitazon grubunda kilo alımı olmuştur (35). Sonuç olarak, liraglutide diabetes mellitus'ta düzelme sağlarken aynı zamanda NAYKH'nda hepatik inflamasyonu azalttğı tespit edilmiştir. Ancak, liraglutide ile ilgili geniş çaplı plasebo kontrollü çalışmalara intiyaç vardır.

\section{Orlistat}

Orlistat, yaklaşık 3 yıldır obezite tedavisinde kullanılan yağ atıımını artırmak suretiyle intestinal yağ emilimini bozan lisanslı gastrik ve pankreatik lipaz inhibitörüdür. NAYKH'nda obezite önemli bir rik faktörüdür. Özellikle obez hastalarda, kilo azaltımını hedeflemeyen tedavi stratejileri başarısız olur. Bu noktada orlistat, diğer ilaçlar ile kombine edilmek suretiyle NAYKH'nın tedavisinde bir alternatif olabilir. Athyros ve arkadaşları anormal karaciğer fonksiyon testleri olan metabolik sendromlu hastalarda orlistat'ı içeren multifaktöryel tedavinin kardiyovasküler olayları azaltmada etki ve güvenilirliklerini inceledikleri çalışmanın sonucuna göre bu yaklaşım hastalarda hem güvenli hem de faydalı bulunmuştur. Bu açıdan bakıldığında orlistat kilo azaltıcı etkisi ile diğer tedavilere alternatif olmak yerine kombine tedavide düşünülmesi akla daha yatkın gelmektedir (36).

\section{Sibutramin}

Obezite ilacı olarak kullanılan yapıca amfetamine benzeyen santral etkili seratonin ve noradrenalin geri alım inhibitörü olan bir ilaçtrr. İştahı azalttı̆ı için obezite tedavisinde kullanılmıştır. Ancak, yan etki insidansı kullanım alanını sınırlandırmaktadır. Orlistat gibi kilo verdirici özelliği nedeniyle gündeme gelmiş ancak, yan etkileri ve alternatif ilaçlar nedeniyle NAYKH'nda tedavide kabul görmemiştir (37). 


\section{Betain}

Betain metioninin metabolik siklusunun normal bir komponenti olarak S- adenozil metioninin bir öncülüdür ve ayrıca hepatoprotektif olarak bilinir. Bundan dolayı NASH tedavisinde potansiyel bir role sahiptir. Bir çalışmada NASH'i olan 10 erişkin hasta üzerinde 1 yıllık betain tedavisinin ardından kontrol edilen ALT ve AST değerleri ile beraber histolojik olarak da önemli düzelme saptandığı gözlemlenmiştir (38). Yine plasebo kontrollü çift kör başka bir çalışmada diğer çalışmaya benzer olarak plaseboya kıyasla hepatik steatozda \%25 daha iyi düzelme saptandığı gözlemlenmiştir (39). Sonuç olarak, betain özellikle NASH tedavisinde alternatif olarak görülse de bu çalışmaların uzun süreli prospektif büyük çalışmalarla konfirme edilmesi gerekmektedir.

\section{Vitamin E ( $\alpha$-Tocopherol)}

Bir antioksidan olarak Vitamin E'nin NASH'li hastalarda kullanımının oksidatif stresi azaltma yoluyla faydalı olabileceği gözlemlenmiştir. Bir çalışmada kronik olarak serum aminoransferaz yüksekliği bulunan çocuklarda günlük olarak 400 ile 1200 IU ilave olarak Vitamin E kullanımının serum amino transferaz düzeylerinde önemli azalma yaptı̆̆ ancak tedavi sonlandırıldığında serum aminotransferaz düzeylerinin tekrar tedavi öncesi duruma geldiği gözlemlenmiştir (40). Harrison ve arkadaşları, NASH'de Vitamin E ve Vitamin C tedavisinin fibrozis üzerine etkisini inceledikleri çalışmada fibrozis skorunda düzelme saptanmış ancak serum aminotransferaz düzeylerinde farklılık saptanmadığı gözlemlenmiştir $(41,42)$. Sanyal ve arkadaşları, Vitamin E ve pioglitazon kombinasyonu ile yalnız Vitamin E'nin karşılaştırıldığı çalışmalarının sonucunda her iki grupta ALT düzeylerinde önemli düzelme sağlanırken, kombinasyon grubunda ayrıca önemli histolojik düzelme de tespit edilmiştir (43). Vitamin E'nin hem yalnız hem de kombine tedavide kullanımı ile ilgili, geniş çaplı, plasebo kontrollü, prospektif çalışmalara intiyaç olduğu kesindir.

\section{$\mathrm{N}$-Asetilsistein}

Asetilsistein doğal bir aminoasit olan L-sistein'in N-asetillenmiş türevi olup mukolitik olarak kullanılan ajandır. Yapısında bulunan sülfidril grubu ile glikoprotein içerisindeki disülfit bağlarını koparma özelliğinden dolayı mukoid ve mukopürülan sekresyonlar üzerine muko- litik etki göstermektedir. Aynı zamanda da antioksidan etkisi bulunan bu ajan, patogenezinde oksidatif stresin rol aldığı NAYKH'nın tedavisinde bir alternatif olarak araştırılmıştır. NAYKH olan 30 hasta üzerinde, N-asetilsistein ile Vitamin C'nin karşılaştırıldığı bir çalışmada, aylık olarak serum transaminaz değerleri ölçülmüştür. Çalışmanın sonunda, Vitamin C grubuna kıyasla N-asetilsistein grubunda ALT düzeyinde önemli azalma olduğu gözlemlenmiştir (44). Bir başka çalışmada, NASH'li 20 hastaya, 12 ay boyunca metformin ve $\mathrm{N}$-asetilsistein kombinasyon tedavisi uygulanıp aminotransferaz ve hepatik fibrozisdeki düzelme izlenmiştir. Çalışmanın sonunda, ALT değeri, karaciğer yağlanması ve fibrozis derecesinde düzelme gözlemlenirken AST değerinde ve lobüler inflamasyonda herhangi bir düzelme gözlemlenmemiştir (45). Sonuç olarak, N-asetilsistein antioksidan etkisi ve sitoprotektif etki ile gerek tek başına gerekse kombine olarak NAYKH'nın tedavisinde alternatif olarak gözükmektedir. Ancak yine de geniş çaplı, plasebo kontrollü, prospektif çalışmalara intiyaç olduğu kesindir.

\section{Probiyotikler}

Obezite veya diyabeti olmayan bir çok hastada da NAYKH görülmektedir. Bunun nedeni olarak başka faktörler üzerinde durulmaktadır. Örneğin, barsakta bakteriyel aşırı çoğalmanın rol oynadığı düşünülmektedir. Burada, barsak florasının ürettiği amonyak ve asetaldehit gibi toksik maddelerin karaciğer üzerindeki toksik etkileri suçlanmaktadı. Üretilen bu maddeler karaciğer tarafindan metabolize edilir ve endotoksinler aracılığıyla salınan sitokinler, Kupfer hücrelerinin hiperplazisine yol açar. Ayrıca, alkole bağlı karaciğer hastalı̆̆ı ile morbid obez hastalar için yapılan jejunoileal by-pass operasyonları sonrası NASH bu yolla oluşmaktadır (46). Probiyotikler canlı mikroorganizmalar olup barsakların sağlıklı kalmasını sağlar ve intestinal bakteriyel enzimleri, mukozal yapışmayı, epitel invazyonunu inhibe eder ve buna karşın immun sistemi situmule ederler. Barsaktaki besinler için yarışı sınırlandırır ve antimikrobiyal maddelerin salınımına neden olurlar. Barsak duvarına tutunan probiyotikler enterik patojen bakterilerin barsak duvarına yapışmasını önlerler (47). Farelerde yapılan çalışmalarda, sonradan geliştirilmiş bakteriyel aşırı çoğalmanın (BAÇ) karaciğerde NASH yaptı̆ı gösterilmiştir. Yine antibiotik tedavisi ile NASH'in gerilemesi bu düşünceyi desteklemektedir. 
Sonuç olarak, oksidatif stres buradaki temel mekanizma olarak kabul edilebilir (46). Son dönemde bu bilgiden yola çıkarak yapılan fare deneylerinde, probiyotik tedavi ile hepatik fonksiyon testlerinin ve NASH'in düzeldiği gösterilmiştir $(47,48)$. Yang ve arkadaşlarının farelerde yaptıkları bir başka çalışmada, endotoksinlerin Tümör Nekroz Faktör-alfa aracılığıyla apopitozu stimule edip steatoz gelişimini artırdıklarını ve NASH'e zemin hazırladıklarını gözlemlemişlerdir (47). Probiyotiklerle ilgli insan çalışmasının azlığı bu konuda yeterli fikrin oluşmamasının nedeni gibi görünmektedir.

\section{Omega-3 yağ asitleri}

Omega 3 yağ asitleri sadece serbest oksijen reaktifleri ve insülin direnci üzerine değil aynı zamanda peroksizom proliferator aktivatör reseptör- $\alpha$ (PPAR- $\alpha$ ), PPAR $\gamma$, sterol regülatör element-binding protein-1, karbonhidrat responsive element-binding protein gibi düzenleyici gen transkripsiyon faktörleri vasıtasıyla ateroskleroz, endotelyal disfonksiyon, hiperlipidemi ve hipertansiyon gibi kardiyo-metabolik risk faktörleri üzerine de faydalı etkileri vardır. Ayrıca, omega 3 yağ asitleri, hepatik beta oksidasyonu artirması ve endojen lipid üretimini azaltmasına ilave olarak TNF-alfa ve interlökin- 6 gibi proinflamatuvar moleküllerin üretimini önemli ölçüde azaltırlar (49). Gerek hayvan gerekse insan çalışmalarında omega 3 yağ asitlerinin labaratuvar parametreleri ve görüntüleme yöntemleri ile NAYKH'nda da faydalı etkileri tesbit edilmiştir (50). Omega 3 yağ asitleri ile ilgili cesaret verici çalışmalar olmakla beraber iyi dizayn edilmiş randomize kontrollü, büyük çalışmalara intiyaç vardır.

\section{KAYNAKLAR}

1. Sonsuz A. Nonalkolik karaciğer yağlanması. http:// www.ctf.edu.tr/stek/pdfs/58/5807.pdf Erişim 23.11.2007.

2. Jansen PL. Nonalcoholic steatohepatitis. Neth J Med 2004;62(7):217-24.

3. Durazzo M, Belci P, Collo A, Grisoglio E, Bo S. Focus on therapeutic strategies of nonalcoholic fatty liver disease. http://www.medscape.com/viewarticle/474880?src=search Erişim 17.10.2012.

4. Dabhi A, Brahmbhatt K, Pandya T, Thorat P, Shah M. Nonalcoholic fatty liver disease. JIACM 2008;9(1):3641.
5. Hajiaghamohammadi A, Ziaee A, Oveisi S, Masroor $\mathrm{H}$. Effects of metformin, pioglitazone, and silymarin treatment on non-alcoholic fatty liver disease: a randomized controlled pilot study. Hepatitis Monthly 2012;12(8):16.

6. Lomonaco R, Chen J, Chen K. An endocrine perspective of nonalcoholic fatty liver disease. Ther Adv Endocrinol Metab 2011;2(5):211-4.

7. Ledinghen $\mathrm{V}$, Vergniol J. Transient elastography for the diagnosis of liver fibrosis. Expert Rev Med Devices 2010;7(6):811-23.

8. Trappoliere M, Tuccillo C, Federico A, Di Leva A, Niosi $M$. The treatment of NAFLD. Eur Rev Med Pharmacol Sci 2005;9(5):299-304.

9. Clark J. Weight loss as a treatment for nonalcoholic fatty liver disease. J Clin Gastroenterol 2006;40(Sup 1):39-43.

10. Harrison S, Kadakia S, Lang K, Schenker S. Nonalcoholic steatohepatitis: what we know in the new millennium. Am J Gastroenterol. 2002 Nov;97(11):2714-24.

11. Vajro $\mathrm{P}$, Lenta $\mathrm{S}$, Pignata $\mathrm{C}$ et al. Therapeutic options in pediatric non alcoholic fatty liver disease: current status and future directions.

http://www.ijponline.net/content/pdf/1824-728838-55.pdf doi:10.1186/1824-7288-38-55 Erişim 12.10.2012

12. Sözen $M$, Türkay $C$. Ursodeoksikolik asit için tubbi endikasyonlar ve etki mekanizmaları. http://guncel.tgv.org. tr/journal/39/pdf/100039.pdf Erişim 2011

13. Grigoreva I. Ursodeoxycholic acid in the treatment of nonalcoholic fatty liver disease. Eksp Klin Gastroenterol 2011;(9):125-31.

14. Trauner M, Graziadei I. Rewiev article: Mechanism of action and therapeutic application of ursodeoxycholic acid in chronic liver disease. Aliment Pharmacol Ther 1999;13:979-96.

15. Kowdley K. Ursodeoxycholic acid therapy in hepatobiliary disease. Am J Med 2000;108(6):481-6.

16. Lindor K, Kowdey K, Heathcote E et al. Ursodeoxycholic acid for treatment of nonalcoholic steatohepatitis: result of a randomized trial. Hepatology 2004;39(3):7708.

17. Vajro $\mathrm{P}$, Veropalumbo C. Citrin deficiency: learn more, and don't forget to add it to list of neonatal cholestasis and the NASH trash bin. J Pediatr 2010;50(6):578-9.

18. Adams L, Angulo P, Petz J, Keach J, Lindor K. A pilot trial of high dose ursodeoxycholic acid in nonalcoholic steatohepatitis. Hepatol Int 2010;28(3):628-33. 
19. Pietu F, Guillaud O, Walter T et al. Ursodeoxycholic acid with vitamin $\mathrm{E}$ in patients with nonalcoholic steatohepatitis: long-term results. Clin Res Hepatol Gastroenterol 2012;36(2):146-55.

20. Shyangdan D, Clar C, Ghouri N. Insulin sensitisers in the treatment of non-alcoholic fatty liver disease: a systematic review. Health Technol Assess 2011;15(38):1110.

21. Boettcher E, Csako G, Pucino F, Wesley R, Loomba R. Meta-analysis: pioglitazone improves liver histology and fibrosis in patients with non-alcoholic steatohepatitis. Aliment Pharmacol Ther 2012;35(1):66-75.

22. Gastaldelli A, Harrison S, Belfort-Aguiar R et al. Pioglitazone in the treatment of NASH: the role of adiponectin. Aliment Pharmacol Ther 2010;32(6):769-75.

23. Harmancı A, Gürlek A. Eski ilaç, eski ve yeni kullanımları: Metformin. http://ichastaliklaridergisi.org/managete/fu_folder/2005-01/html/2005-12-1-029-037.htm Erişim 01.10.2012

24. Mazza A, Fruci B, Garinis GA, Giuliano S, Malaguarnera $R$, Belfiore $A$. The role of metformin in the management of NAFLD. Exp Diabetes Res 2012;2012:716404.

25. Akcam M, Boyaci A. Pirgon O et al. Therapeutic effect of metformin and vitamin E versus prescriptive diet in obese adolescents with fatty liver. Int J Vitam Nutr Res 2011;81(6):398-406.

26. Chatrath $H$, Vuppalanchi R, Chalasani N. Dyslipidemia in patients with nonalcoholic fatty liver disease. Semin Liver Dis 2012;32(1):22-9.

27. Dima A, Marinescu A, Dima AC. Nonalcoholic fatty liver disease and the statins treatment. Rom J Intern Med 2012 2012;50(1):19-25.

28. Nseir W. Mograbi J, Ghali M. Lipid-lowering agents in nonalcoholic fatty liver disease and steatohepatitis: human studies. Dig Dis Sci 2012;57(7):1773-81.

29. Tzefos M, Olin JL. 3-hydroxyl-3-methylglutaryl coenzyme $A$ reductase inhibitor use in chronic liver disease: a therapeutic controversy. J Clin Lipidol 2011;5(6):450-9.

30. Hyogo H, Yamagishi S, Maeda S et al. Atorvastatin improves disease activity of nonalcoholic steatohepatitis partly through its tumour necrosis factor- $\alpha$-lowering property. Dig Liver Dis 2012;44(6):492-6.

31. Hyogo H, Tazuma S, Arihiro K et al. Efficacy of atorvastatin for the treatment of nonalcoholic steatohepatitis with dyslipidemia. Metabolism 2008;57(12):1711-8.

32. Onat A, Ceyhan K, Sansoy V ve ark. Erişkinlerimizin yarısında bulunan dislipidemi ve metabolik sendromun özellikleri ve kombine hiperlipidemi ile ilişkisi; aynı za- manda plazma trigliserid düzeyi üst sınırı konusunda bir katkı. Arch Turk Soc Cardiol 2001;29(5):274-85.

33. Fernandez -Miranda C, Perez- Carreras M, Colina F et al. A pilot trial of fenofibrate for the treatment of non-alcoholic fatty liver disease. Dig Liver Dis. 2008 Mar;40(3):200-5.

34. Zambon A, Cusi K. The role of fenofibrate in clinical practice. Diab Vasc Dis Res 2007;4(Suppl 3):15-20.

35. Ohki $T$, Isogawa $A$, Iwamoto $M$ et al. The effectiveness of liraglutide in nonalcoholic Fatty liver disease patients with type 2 diabetes mellitus compared to sitagliptin and pioglitazone. ScientificWorldJournal 2012;2012:496453.

36. Athyros VG, Giouleme O, Ganotakis ES et al. Safety and impact on cardiovascular events of long-term multifactorial treatment in patients with metabolic syndrome and abnormal liver function tests: a post hoc analysis of the randomised attempt study. Arch Med Sci 2011;7(5):796-9.

37. Süzer Ö. Santral Sinir Sistemi Situmulanları ve Psikotomimetik ilaçlar. http://www.ctf.edu.tr/farma/onersuzer/pdf/tr/12_SSS_stimulanlari.pdf Erişim 3.10.2009

38. Abdelmalek MF, Angulo P, Jorgensen RA et al. Betaine, a promising new agent for patients with nonalcoholic steatohepatitis: results of a pilot study. Am J Gastroenterol 2001;96(9):2711-7.

39. Miglio F, Rovati LC, Santoro A et al. Efficacy and safety of oral betaine glucuronate in non-alcoholic steatohepatitis. A doubleblind, randomized, parallel-group, placebo-controlled prospective clinical study. Arzneimittelforschung 2000;50(8):722-5.

40. Lavine JE. Vitamin E treatment of nonalcoholic steatohepatitis in children: a pilot study. J Pediatr 2000;136(6):734-8.

41. Harrison $S$, Torgerson $S$, Hayashi $P$ et al. Vitamin $E$ and vitamin $C$ treatment improves fibrosis in patients with nonalcoholic steatohepatitis. Am Gastroenterol 2003;98(11):2485-90.

42. Adams LA, Angulo P. Vitamins $E$ and $C$ for the treatment of NASH: duplication of results but lack of demonstration of efficacy. Am J Gastroenterol 2003;98(11):234850.

43. Sanyal AJ, Contos MJ, Sargeant C. A randomized controlled pilot study of pioglitazone and vitamin $E$ versus vitamin $E$ for nonalcoholic steatohepatitis. Hepatology 2002;36:A-382. 44. Khoshbaten M, Aliasgarzadeh A, Masnadi $K$ et al. $\mathrm{N}$-acetylcysteine improves liver function in patients with non-alcoholic Fatty liver disease. Hepat Mon 2010;10(1):12-6. 
45. de Oliveira CP, Stefano JT, de Siqueira ER et al. Combination of $\mathrm{N}$-acetylcysteine and metformin improves histological steatosis and fibrosis in patients with non-alcoholic steatohepatitis. Hepatol Res 2008;38(2):159-65.

46. Bektaş $M$, Özden A. Barsak florası, probiyotikler ve karaciğer hastalıklarında probiyotiklerin yeri. Güncel Gastroenteroloji. http://guncel.tgv.org.tr/journal/18/ pdf/203.pdf Erişim 01.06.2006

47. Li Z, Yang S, Lin $\mathrm{H}$ et al. Probiotics and antibodies to TNF inhibit inflammatory activity and improve nonalcoholic fatty liver disease. Hepatology 2003;37: 343-50.
48. Loguercio C, Simone TD, Federico A et al. Gut-liver axis: a new point of attack to treat chronic liver damage? Am J Gastroenterol 2002;97:2144-6.

49. Minno M, Russolillo A, Lupoli R et al. Omega-3 fatty acids for the treatment of non-alcoholic fatty liver disease. World J Gastroenterol 2012;18(41):5839-47.

50. Alfin-Slater RB, Bernick S. Changes in tissue lipids and tissue histology resulting from essential fatty acid deficiency in rats. Am J Clin Nutr 1958;6(6):613-24. 